\title{
The European Union's Need for an International Auxiliary Language
}

\author{
Federico Gobbo
}

Insubria University

\begin{abstract}
In the last few years, debate has centered around European Union language policy. Many people, language specialists and laymen alike, argue that the European Union should adopt a common tongue for practical purposes, at institutional and educational levels, while respecting the cultural richness of other languages. Although English, or sometimes Latin, has been proposed, an International Auxiliary Language (IAL) would seem to accomplish this aim better. In this paper we will compare, structurally and sociolinguistically, three major IALs: Esperanto, Ido, and Interlingua, as candidates to serve as the common language of the $\mathrm{EU}$, on account of their language vigour and vitality.
\end{abstract}

Keywords: International Auxiliary Language, European Union, language politics, English, Esperanto, Ido, Interlingua, Latin 
2 The European Union's Need for an International Auxiliary Language

\section{Introduction}

May 1, 2004 is a crucial date in European history: twenty-five European countries created the most important political reality the Old World ever dreamed of. With its 455 million citizens, the European Union became more populous than the United States of America, as well as topping the USA's Gross Domestic Product (GDP), making it the largest economy in the world (Rifkin 2004). Conversely, as has been noted elsewhere, after September 11, 2001, the appeal of United States' world leadership has greatly declined (Jung 2004).

Despite these data, the political relevance of the EU in the world is not as important as its economy. It is worth recalling that the creation of a new Europe, after the Second World War, was driven by two agendas, one European, the other American (Phillipson 2004). So, the main cause of limited European influence in world politics has been political from the very start of the EU, because of the USA as well as France and Germany. Brussels' governing machinery has been widely criticized as bureaucratic, EU protocols and directives - the main tools for European policies - are often ineffective, since France and Germany impose conditions that are favorable for themselves as opposed to the interests of smaller countries, or by simply not obeying EU directives. Some columnists have coined the term "Framany" to make light of the heavy-handed collateral policy of France and Germany.

Moreover, the Euro, the common European currency, is viewed by most as imposed by Brussels' institutions, and small and large nationalisms have emerged in many member countries as a protest against EU political decisions. But an emerging European Dream can be considered the main vehicle of a new European identity. As Rifkin (2004) remarked, the European Dream emphasizes community relationships over individual autonomy, sustainable development over unlimited material growth, universal human rights 
and the rights of nature over property rights. So, what is missing from the EU to keep it from becoming better appreciated by its citizens? In my opinion, Europeans need a simple but crucial common denominator to feel at home in every member country: a common language.

\section{European Union Language Politics: State of the Art}

Never has an international institution adopted such a difficult language policy as the European Union. For example, the United Nations with over 170 member countries at present, in contrast to 25 EU countries, has adopted 5 official languages (English, French, Arabic, Chinese, Russian), whereas the EU has 20 (see below). Let's assume, for simplicity, that every EU citizen speaks at least one official language as a first language (while not actually very true, this is a good enough assumption for our analysis). The following are the official EU languages as of May 1, 2004, in alphabetical order.

To sum up, Romance languages number about 169 million native speakers; Germanic languages, 163 million; Slavic languages, 63 million. Less diffused language families are: Finno-Ugric (17 million native speakers), Scandinavian (12 million), Greek (10 million), Baltic (4.5 million), Semitic (half a million). Scandinavian languages share some general characteristics with the Germanic, and Baltic languages share both Germanic and Slavic features.

Henceforth, an official IAL for the EU should be respect the mother tongue features of most Europeans, as much as possible. 
4 The European Union's Need for an International Auxiliary Language

Table 1. Official EU Languages

\begin{tabular}{|l|l|r|}
\hline Language name & Typological family & Native speakers in $\mathrm{EU}^{1}$ \\
\hline Czech & Slavic & $10,000,000$ \\
\hline Danish & Scandinavian & $5,000,000$ \\
\hline Dutch & German & $18,000,000$ \\
\hline English & German & $58,000,000$ \\
\hline Estonian & Finno-Ugric & $1,000,000$ \\
\hline Finnish & Finno-Ugric & $6,000,000$ \\
\hline French & Romance & $62,000,000$ \\
\hline German & German & $87,000,000$ \\
\hline (Modern) Greek & Greek & $10,000,000$ \\
\hline Hungarian & Finno-Ugric & $10,000,000$ \\
\hline Italian & Romance & $56,000,000$ \\
\hline Latvian & Baltic & $1,500,000$ \\
\hline Lithuanian & Baltic & $3,000,000$ \\
\hline Maltese & Semitic & 500,000 \\
\hline Polish & Slavic & $46,000,000$ \\
\hline Portuguese & Romance & $11,000,000$ \\
\hline Slovak & Slavic & $5,000,000$ \\
\hline Slovene & Slavic & $2,000,000$ \\
\hline Spanish & Romance & $40,000,000$ \\
\hline Swedish & Scandinavian & $7,000,000$ \\
\hline
\end{tabular}

\subsection{A Brief History of EU Language Politics}

"Any discrimination based on any ground such as sex, race, color, ethnic or social origin, genetic features, language, religion or belief, political or any other opinion, membership of a national minority, property, birth, disability, age or sexual orientation

\footnotetext{
1 As of the year 2000, there has been no official EU updating for these numbers, so they should be regarded as a rough estimate, based on data from individual EU countries (source: EU official web site $<$ http://europa.eu.int $>$ ).
} 
shall be prohibited."

Treaty Establishing a Constitution for Europe 2004, III, II-81

To understand how ideal and optimistic the European Constitution is, we should recall that the European Union was formed with particular attention to universal human rights, including rights regarding languages.

When Robert Schuman, former French Minister of Foreign Affairs, launched the idea of a European Union in 1950, the main goal was to create a politically sovereign institution that could establish a permanent state of peace in the Old World. The year 1950 marked but the fifth anniversary of the end of the Second World War, and the policy of the Union's founders followed the "never again" imperative. Indeed, with the tragic exceptions of Ulster (the contested British region in Ireland) and the Basque lands (the contested Spanish region near the French border), this goal has been successful. Among EU member countries there has been no war since 1950 .

Conversely, much less attention has been paid to language policy. The official languages of the European Coal and Steel Community (ECSC), the first nucleus of the European Union established in 1951, were four (Dutch, French, German, and Italian), and they enjoyed equal status throughout the Union: although not really equal, a sustainable situation, similar to that in Switzerland. In 1958, when the first Treaty of Rome was signed and the European Economic Community (EEC) was created, there were six members (Belgium, France, Germany, Italy, Luxembourg, and the Netherlands), and only fifteen interpreters and translators. Authorities and individuals in the member states were free to decide which of the official languages they wanted to use, and in consequent treaties there have been no changes in this policy.

After peace, the main efforts of European politicians were devoted to economics, i.e., establish stable cooperation between 
6 The European Union's Need for an International Auxiliary Language

member countries to create a common market. The Euro, the common currency adopted by most members, is the most evident success in this regard. On the other hand, language policy to construct a 'United States' of Europe - the long-term goal-was never be in the daily political agenda. In principle, maintaining linguistic and cultural diversity in Europe is an essential precondition for peace on the continent, but in practice, the dictates of efficiency were followed to enable the EU to work well. Specifically, the more European the Union and its institutions have grown, the more English has been used. For example, EU agencies adopt as working languages mostly English, and sometimes French and German (Gazzola 2003:40).

However, the Constitution as cited above established the principle that every official language is equal to the others. This has led to the schizophrenic situation in Europe we face today with twenty official languages, theoretically equal in dignity, but in practice some languages are more equal than others, to paraphrase George Orwell.

\subsection{EU Language Politics: Facts are Stronger than Principles}

It is evident that no institution with twenty official languages can afford interpretations and translations for every transaction involving every language, and the European Union is no exception. ${ }^{2}$ In fact, an interpreter or translator working in EU institutions should translate only into his or her first language. Finding an interpreter whose native tongue is, for example, modern Greek, with a good command of Finnish or Maltese might prove to be difficult.

So, the solution often adopted is 'asymmetric interpretation', with the European parliament as the most prominent case. Every member of the European Parliament (MEP) may speak officially in

${ }^{2}$ We use the term 'interpretation' for immediately translation of speech, and the term 'translation' for written translation of documents, as per EU terminology. 
his first language, but MEPs who are native speakers of a minor language will most likely hear replies in a major language, i.e., English, French, or German. Moreover, interpreters may adopt the so-called 'relay language' policy. If a MEP is speaking, for example, in Finnish, which the interpreter doesn't understand, he or she could listen to a colleague's translation from Finnish into English, which serves as a 'relay language', and then translate into his or her mother tongue (DGI 2004).

Data regarding translation are even more indicative. In 2003, when there were eleven official languages, $58.9 \%$ of the $1,416,817$ pages of draft documents were written in English, 28.1\% in French, $3.8 \%$ in German, and $8.9 \%$ in other languages. Moreover, the trend shows a dramatic increase of drafts in English. Conversely, the target languages of the translated draft papers were German, French, and English, respectively.

Contrary to what one might expect, the costs of this multilingualism are not so high. In 1999, the last year in which such costs were calculated, interpretation and translation amounted to 685.9 million Euros, i.e. not more than 2 Euros a year for each EU citizen-the equivalent of a cup of coffee. In the same year, the European Union invested 59 times as much or 40,490 million Euros for agriculture.

\section{International Auxiliary Languages vs. English: A Challenge for the European Union}

Today there is ferment in a few political parties and among some avant-garde European intellectuals to radically change the language policy of the European Union. A European Federation of National Institutions for Language (EFNIL) was established in Stockholm in 2003, consisting of academies which protect and regulate languages from all over Europe. The EFNIL redacted a document about European language policy, called the 'Mannheim-Florence Recommendations', 
8 The European Union's Need for an International Auxiliary Language

suggesting that the educational curriculum in every member country should foster multilingualism. ${ }^{3}$ Every citizen should speak at least three languages: the official language where he or she actually lives, another for business or practical purposes, and a third language as he or she pleases, perhaps a classical language such as Latin, or a minor language to affirm his or her local identity, or any other European language.

The Recommendations do not specify the language for "practical purposes." We will analyze the pros and cons of five candidates for this role. English, the de facto global language, will be considered the most probable but also the most controversial candidate. Then we will examine Latin, which has kindled renewed interest lately, and finally, three International Auxiliary Languages (IALs), Esperanto, Ido, and Interlingua. These IALs satisfy three essential criteria: relative ethnically and political neutrality for Europeans, robust regularity so to be learned easy and quickly, and functionality, and they function as a living language (Lee 2001:52).Esperanto, Ido and Interlingua each have their own speech community ${ }^{4}$ and history, testifying to their successful functioning. We will determine which of these 5 candidates is best suited to serve as the common language of European citizens.

First of all, we will briefly present the historical context in which each language arose; without this, many language traits remain puzzling. Then, we will analyze each language, first structurally, to determine language substrata, its phonetics and writing systems, the language's relation to official EU languages; and then sociolinguistically, to construct a profile by examining the size of its speech community, quantity and quality of literature, and presence on the world wide web.

\footnotetext{
3 Available in English at $<$ http://www.eurfedling.org/rac/raceng.htm>.

4 In this paper, we consider 'speech community' as "the product of the communicative activities engaged in by a given group of people” (Duranti 1997:82).
} 
Structural analysis will reveal how many European citizens may find the candidate language familiar without studying it due to its phonology, writing system and lexicon and after non-intensive study because of its morphology and syntax. The socio-linguistic profile will present, when possible, official data about the language's speech community, i.e., the number of fluent speakers in the EU. As a parameter of its presence on the world-wide web, we will compare the number of entries of the candidate language in Wikipedia, a free encyclopedia written by volunteers. This work-in-progress is coming to the attention of more and more web analysts, because in only four years it has become larger and is perhaps consulted more often than the Encyclopædia Britannica. For IAL enthusiasts, Wikipedia provides the perfect opportunity for producing documents in their favourite IAL. They can promote their own language at almost no cost, except for personal time, and the IAL speech community controls the entries, so their quality can be taken for granted. Likewise, the number of entries can be indicative of a language's vitality, an important characteristic if it is to serve as the EU's common language.

\subsection{English or the Power of the Strongest}

Many people, including some influential linguists, observe that the diffusion of English as a global language, due to globalization, is a unique phenomenon in history, and is irreversible (e.g., Crystal 1997). So, the most 'natural' choice for the EU would be to make English its official common language. In the last few years, however, other linguists, in the name of universal and language rights, have observed that globalization in terms of language is synonymous to 'Englishisation' (term used by Phillipson 2004) and that a linguist's first moral duty is to establish a global 'ecology of languages' policy (Tsuda 2004). Indeed, this $j$ ' accuse of the role of English as a global language is not without foundation. Recent data from UNESCO are 
10 The European Union's Need for an International Auxiliary Language

astonishing: in the next century only 600 of the 6,000 known languages will survive, mostly because of globalization. Even national languages with great traditions, such as French, German, and Italian, have increasingly been using English as their Dachsprache (tegment language, i.e., the language that serves as a model). A relevant example can be taken from France: the criticized Toubon law of 1994 tries to defend the French language from linguistic miscegenation with the English language, sometimes called 'franglais.'

Actually, English cannot become more than an official language, as every official language of the Union enjoys equal status, at least in theory. But, if the political plan of the English MEP Natrass, a member of the UKIP (United Kingdom Independence Party), succeeds, i.e., to withdraw the United Kingdom from the European Union by 2010, English could be retired as an official language to be re-employed as the common language. This is the scenario we will analyze now.

\section{(1) Structural Analysis}

The history of English shows that this language possesses an extraordinary degree of hybridism as a result of its receptiveness to new words from every language in the world, a characteristic admired by A. Gode (see below).

The price for this receptiveness is a great disparity between phonology and its writing system, which follows an etymological principle. We can distinguish two basic approaches in writing systems: the etymological, which tends to respect the 'correct' writing form of language substrata (in German: Schriftbild), and the phonemic, which observes the principle of one sound per letter, (in German: Lautbild). It is generally accepted among specialists that a phonemic approach is preferable in an IAL. Moreover, English contains many vowels (at least 12), far more than the optimum for an IAL, which has been fixed at 5 (Jung 2004: 35). Considered as an 
IAL, English lacks fundamental features: regularity in word formation, neutrality in ethnic coverage, and a phonemic writing system.

(2) Socio-linguistic Profile

The presence of English has become increasingly pervasive as time goes by. For many Europeans, English is the first choice as a second language and, generally speaking, native speakers of German and Scandinavian languages seem to learn it better because of similarities in structure, compared to speakers of Romance and Slavic languages. The European educational system has unanimously adopted British, not American, English as its norm (Crystal 1997).

This can lead to a problem: the emergence of a third variety of 'continental' English, which has been in progress for some time now. For example, it is not rare to find in continental Europe street signs with "car parking" on them instead of the correct British English "car-park."

Needless to say, the quality of English literature and its presence on the web is enormous, far more than any other language, artificial or otherwise. Wikipedia entries in English, as of February 1, 2005, numbered 465,415. Finally, for most Europeans, studying English is a 'necessary evil', rather than a matter of choice.

\subsection{Latin or a Language Revival with European Roots}

Latin is obviously not an IAL, but its language vitality nowadays is comparable to other IALs. After the fall of the Western Roman Empire in the $5^{\text {th }}$ century, spoken Latin was the starting point of national languages that eventually have become the Romance languages. As the official language of the Catholic Church and the only liturgic language of Catholics until the past century, Latin has 
12 The European Union's Need for an International Auxiliary Language

maintained its prestige. Until the scientific revolution in $17^{\text {th }}$ century Europe, Latin was the only written language of European clergymen, scholars, and government officials. However, even later, in 1904, Giuseppe Peano, the Italian mathematician, proposed a simplified form of Latin, called Latino sine flexione, as the IAL for scholars (Peano 1904). This in turn was an inspiration for Interlingua (see below).

The rise of the Nation-State in Europe, starting from the French Revolution, conferred dignity to national languages. In the case of French, German and Italian, national education systems made their native tongue the first language of every national citizen, and this process took place over the course of a century.

The vitality of Latin declined with the rise of national languages. Now, supporters of Latin as the European IAL maintain that to create a European 'United States', Europe should return to its roots, both linguistic and religious i.e., Christian. This program resembles Ben-Yehuda's Modern Hebrew revival, which bound the destinies of Israel and the Hebrew language (Hagège 2000). Arguably, there is no theoretical impediment to a revival of Latin in Europe. The main problem seems to be its vocabulary, which has to be thoroughly and constantly updated for modern needs. Individual Latin enthusiasts do this during their international meetings, as do the supporters of other IALs, but without a central authority.

(3) Structural Analysis

The history of Latin is magnificent and very long: the language had undergone a profound evolution. Latin grammar had a standard written norm around the 1st century b.c. Since then, its morphology was fixed and dictionary entries were taken mainly from classical authors: Caesar, Cicero, Virgil, Tacitus, Seneca. Authors in the Middle Ages followed these models. Interestingly, under the influence of the spoken varieties of vulgar Latin, i.e., the forms which 
would give rise to the Romance languages, word order gradually shifted from SOV to SVO, e.g., in Augustine's writings. This writing system, of course, follows the etymological principle, which is the model for English and Interlingua.

The Latin alphabet originally had only 21 letters: the graphemes $/ \mathrm{k} /, / \mathrm{y} /$ and $/ \mathrm{z} /$ were introduced later, under the influence of Ancient Greek. The 5 vowels in Latin, the model for every IAL, originally had a quantitative value: e.g. $\breve{a}$ indicates short stress, $\bar{a}$ indicates long, and this was the way to indicate cases. Nobody has tried to reintroduce them in Latin as an IAL, so we can consider contemporary Latin as a 5-vowel language.

There is no general agreement among scholars as to Latin's phonology, i.e., we don't know how Romans pronounced Latin in its classical Epoch (200-1 b.c.). The Catholic Church's influence in pronunciation was very significant, so some Latin speakers' pronunciation is very similar to contemporary Italian. Others prefer a more phonemic-oriented approach, based on philological research, as described by Giuseppe Peano in his proposal Latino sine flexione (Peano 1904). Here is an example of contemporary spoken Latin (the description of a football derby in Turin):

Hodie est Dominica extraordinaria: magna pars Taurinensium relinquit domum et cetera negotia et affluit ad stadium: duae enim turmae eiusdem urbis certabunt inter se maxima alacritate. (Angelino 1988)

Today it is an extraordinary Sunday: most Turinese have left home and other affairs and have converged on the stadium: in fact their two city teams will fight one another with the utmost vigor. 
14 The European Union's Need for an International Auxiliary Language

['odje 'est do'minika ekstra'ordinarja: 'ma a 'pars t ri'nenzjum re'linkwit 'domum et 't etera ne'gotsja 'et 'aft/wit 'ad 'stadjum 'due 'enim 'turme 'ejuzdem 'urbis t er'tabunt 'inter 'se 'maksima alakri'tate.] (Ipa, Italian pronunciation).

[ho'die 'est do'minika ekstraordina'ria: 'magna 'pars tawri'nensium re'linkvit 'domum et 'tsetera ne'gotja 'et af:'luit 'ad stad'ium 'duae 'enim 'turmae 'ejusdem 'urbis tser'tabunt 'inter 'se 'maksima alakri'tate.] (Ipa, philological pronunciation. The differences are in italics).

Moreover, the main difficulty faced by Latin teachers as a living language is getting students to speak informally but correctly. The proximity of Latin to the Romance languages results in students 'pidginizing' Latin with, for example, Italian, creating an unacceptable mix, unfit for any use except as jargon, a secret language for peer groups (Angelino 1999).

(4) Socio-linguistic Profile

It is very difficult to estimate the number of Latin speakers in the EU today. Many EU citizens have some command of Latin as a classical language, but not for speaking purposes. Consequently, these people would not attribute great importance to the publication of the Latin translation of the first Harry Potter book, Harry Potter and the Philosopher's Stone, an English best-seller worldwide, Herrio Pottero et Philosophi Lapis (Rowling 2003).

We will count readers of the Latin version as members of the contemporary Latin speech community, i.e., an IAL. The only other concrete sign of Latin speakers is their meetings: in the last fifty years there have been many all over the world, but with never more than one hundred people. There is also a group supporting Latin as a 
first language (L1) in families ${ }^{5}$. So we can generously estimate about 1,000 Latin speakers in the European Union. On Internet they have chat rooms as well as web sites and even a web radio. As of February 1, Wikipedia had 2,568 entries in Latin, more than Ido or Interlingua.

\subsection{Esperanto or the Force of Tradition}

As is known, Esperanto was published in 1887 by an Ashkenazi, L. L. Zamenhof. This oculist was deeply influenced by the Haskalah (Jewish Enlightenment), an intellectual movement which, according to the Encyclopædia Britannica, "attempted to acquaint Jews with the European and Hebrew languages and with secular education and culture as supplements to traditional Talmudic studies." When studying in Moscow (1879-1881), he also became interested in the 'Jewish question'. Like other intellectuals, he was convinced that Jews had to create a new literature to survive in modern times, so he proposed a standardization and an orthographical reform of Yiddish, very similar to the yet to be created Esperanto alphabet. Unfortunately, his article, the first grammar of Yiddish ever written, remained unpublished until 1909 (Holzhaus 1969). Coming back to Warsaw in 1881, Zamenhof started a Zionist circle, Hibbat Zion ('Lovers of Zion').

Unlike Ben-Yehuda and most Zionists, L. L. Zamenhof was convinced that the relationship between the Jewish nation and the Jewish religion had caused the isolation and consequent misery of the Jews. For him, the 'Jewish question' could be solved with a twopart project. The first part, named 'Hillelism', called for a return to pure monotheism, dominated by rationality and tolerance for other religions (Meisl 1917).

\footnotetext{
5 Its name is Societas Familiarum Latinarum. See <http://members.lycos.co.uk/ avitus2002/indexsfl.html>.
} 
16 The European Union's Need for an International Auxiliary Language

The second part was political and linguistic: the creation of a community with a rationalized language, neutral with respect to nationality, for use in every public context, especially by Jews (Zamenhof 1929). This language had to capture the Sprachgeist ('Spirit of the Language') of Yiddish and Sefardi languages: that language was to become Esperanto. That's why Esperanto has five vowels - as in the Sephardic tradition - and so many consonants; it's no coincidence that the consonants of Yiddish and of Esperanto are the same (Bausani 1974). This is the origin of the somewhat 'strange' (for IAL purposes) Esperanto alphabet, and one of its most criticized aspects, since its launch ${ }^{6}$.

(4) Structural Analysis

From the northeastern and deep Slavic-influenced dialect of Yiddish spoken by Zamenhof, Esperanto took some general characteristics: its high hybridism degree, most of its phonology (Pennacchietti 1987), flexibility of word order (due to its accusative case), and a small but important part of its lexicon, the speech discourse signals (Piron 1984).

The official lexicon of Esperanto now, expanding Zamenhof's original (Zamenhof 1905), has only 4,413 morphemes. The morphological structure of Esperanto and its freedom in forming compound words adequately compensate for the number of morphemes. A corpus-based study showed that 6,000 most frequently used terms in English correspond to about 850 Esperanto roots, which undoubtedly facilitate learning the language (Gledhill 2000).

Although the lexicon comes mostly from Latin, ancient Greek and French, but with a relevant part from German, English, Russian and Polish, Esperanto cannot be typologically considered a

6 The other reason is technology: in that time typewriter keyboards were based on French and on German, so it was no problem to print Esperanto's special characters. 
Romance language. Its facility in creating compound words like German (e.g., akvofalo means 'waterfall') and its substantially agglutinative strategy in forming words puts it surprisingly closer to languages like Hungarian, Finnish or Turkish, than to the HindoEuropean family.

For Europeans, an Esperanto written sentence is unreadable without previous study, although many Europeans will distinguish a lot of word roots, but almost everyone can find something familiar to his native tongue after a few lessons.

(5) Socio-linguistic Profile

The Esperanto speech community survived two world wars, and the lowest estimate of the Esperantist community is made by Large (1985): 50,000 people worldwide, at least half of whom are in Europe. Interestingly, the language has evolved since Zamenhof's time. Now there is a juvenile jargon, English influences in the lexicon (author's observation). Esperanto is use in a lot of different contexts: it is used for scientific purposes in some Universities around the world, as well as by a thousand of families as their everyday language (Corsetti 1994), similar to the first era of the Modern Hebrew revival, before the founding of first-level schools. According to some linguists, Esperanto is starting to a 'naturalization process', i.e., to become a first language (Bergen 2001).

In some contexts, such as math terminology, the Esperanto dictionary has too many variants, mainly because few mathematicians use it. However, the quality of literature, including original material, is very high, and it even claims a poet candidate for the Nobel prize in literature, William Auld, a Scotsman. Its presence on the worldwide web makes Esperanto one of the most used languages in the world, after English, Spanish, French, German, Portuguese and 
18 The European Union's Need for an International Auxiliary Language

Italian. Wikipedia entries as of February 3, 2005, numbered 20,139, far more than any other IAL rival.

\subsection{Ido or the Unwanted Offspring of Esperanto}

The main character of Ido (which means 'offspring') that distinguishes it from Esperanto is the absence of every Yiddish and Slavic influence, and a drastic reduction of Germanic traits, except for English.

(6) Structural Analysis

There is no accusative case by morphology, so word order is strictly SVO. On the other hand, phonetics and morphology are nearer to the Romance prototype.

For example, compare the following sentences:

(7) a. La tablo kaj la seĝoj estas en la cambro. (Esperanto)

b. La tablo e la stuli esas en la chambro. (Ido)

'The table and the stools are in the room.'

(8) a. Ni scias, ke ligno estas tre utila (Esperanto)

b. Ni savas ke ligno esas tre utila (Ido) 'We know that wood is very useful.'

In (7a) we can guess at the word 'stool' in stuli, which testifies to the influence of English in Ido. The plural form of Ido is clearly borrowed from Italian. For example, we can compare the strategies for plural (tree/trees) arbo/arbi (Ido) with albero/alberi (Italian), very different from arbo/arboj (Esperanto). In fact, the morpheme $-i$ means both 'masculine' and 'plural', unlike the agglutinative model of Esperanto. Ido prefers borrowing to make new roots instead of creating compounds on the German model, as in Esperanto. Moreover, Ido does not use Esperanto's phonemic writing system, 
but favors close adherence to the English-Latin alphabet, with $x$ representing [ks], and $q u$ representing [kw], a strategy similar to Unish (Jung 2004: 34).

In short, Ido has discarded the delicate equilibrium of Esperanto grammar in favor of a clearer but narrower direction: occidentalization. Its grammar may prove unsatisfactory to many EU citizens, as well as speakers of Slavic and Germanic languages, except English. However, most speakers of the Romance group (even if it may 'sound bad', especially to Italians) may be satisfied as there is a certain degree of familiarity at first glance, more than with Esperanto. Of course, Maltese, Hungarian and Finnish peoples cannot find anything familiar.

(9) Socio-linguistic Profile

Although there is an association for the spreading of $\mathrm{Ido}^{7}$, there is no estimate of the speech community of Ido nowadays, who have started to reorganize themselves in the last few years, thanks to Internet (until 1970, Ido community was made up mostly of Esperantists, who lived a 'double IAL identity').

There is no credible estimate of the Ido speech community. In any case, some signs indicate a status equivalent to an endangered language, unlike Esperanto. The most recent bibliography of Ido shows, that its literature production is almost that of an endangered language: almost no one has published a book in Ido for more than twenty years (Carlevaro-Haupenthal 1999). Similarly, there is little Ido-sustaining activity on the web. It's not simple to follow a language course on-line, even in English, or to download a grammar and a basic dictionary. However, there is a presence of Ido in

7 The only web site worthy a regular reading about Ido is the official one: $<$ http:// www.idolinguo.com>. 
20 The European Union's Need for an International Auxiliary Language

Wikipedia: as of February 3, 2005 there were 2187 entries.

\subsection{Interlingua or Latin as it should be Spoken}

The artificial language movement didn't stop proposing IALs with the launch of Ido (Large 1985). About a thousand projects were started in the past century (Albani-Buonarroti 1994): among them, Novial of Otto Jespersen and Occidental/Interlingue of Edgard De Wahl, one of the first Esperantists. None of them survived the Second World War, except Ido and Interlingua. The common characteristic of every project is the emphatic occidentalization of language structures, sometimes called 'naturalization', and Interlingua is indeed the most occidental in this sense.

IALA (International Auxiliary Language Association), which financed the project, called on linguists to plan a new IAL. The final result, Interlingua, is essentially the creation of the American philologist Alexander Gode, who gave the final touches to the project before its launch after his last rival, André Martinet, decided to leave (Martinet 1989).

Inspired by research in the 'Standard Average European' by Benjamin Lee Whorf, Gode's aim was to devise a codification of the common norm which is embedded in the multiple linguistic variants of the Greco-Latin European tradition. This is Interlingua. (Gode 1962)

The method used to construct the language was the opposite of the IALs previously examined. By comparing the lexicon entries of Italian, Spanish and/or Portuguese, French, English, with German and Russian as control languages, the prototypical form of the lexicon entries, as theoretically spoken in $5^{\text {th }}$ century vulgar Latin, was found (Duggan 1945).

(10) Structural Analysis

Interlingua, the result of twenty-five years of IALA activity, 
is a regularized Romance language that pays special attention to Latin-derived English lexicon.

The first Interlingua-English dictionary, with about 27,000 entries, was published in 1951: the language entered its semiotic life, i.e., no further structural change could be made by its creators, because it started being used. In that dictionary, Interlingua's grammar was also described (and consequently codified) by Gode and Huge E. Blair, a member of the team led by Martinet. The Interlingua writing system, according to Gode, had to follow the etymological principle of English. Interestingly, in paragraph 15 of the first fundamental grammar the authors - maybe Blair - chose to write the language in an alphabet analogous to Italian, i.e., more phonemic, e.g., instead of writing philosophia, phylogenesis or chlorophylla, an Interlingua user can write filosofia, filogenesis or clorofilla. For a philologist, the distinction between the morphemes phil- as in 'philosophy', phyl- as in 'phylogeny' and -phyll- as in 'chlorophyll' might be important, but there is general consensus in using a phonemic writing system for a better IAL (Jung 2004:33). Interestingly, after fifty years of usage, some parts of the lexicon shifted from philological to more Romance-like forms: e.g., emer ('to buy') was replaced by comprar; sed ('but') by mais, and nimis ('too much') by troppo.

Word formation in Interlingua is more difficult compared to Esperanto or Ido: what Esperanto forms with about 30 prefixes and suffixes Interlingua forms with 125 . The reason may lie in the intrinsic irregularity of Romance languages adopted by Interlingua: 3 suffixes for infinitives (-ar, -er, -ir) for Interlingua vs. 1 suffix for Esperanto or Ido; 4 suffixes for duration form (-ation for -ar verbs, -ition for -er and -ir verbs, -ion for irregular [sic] verbs) vs. 1 suffix for Esperanto or Ido; and so on. The verbs inherited the complex structure of Romance languages, in Latin consecutio temporum, which makes learning it very difficult for native speakers of 
22 The European Union's Need for an International Auxiliary Language

Germanic (English included), Slavic, Finno-Ugric or Baltic languages.

Interlingua has a great advantage over every competitor because it is immediately readable for Romance speakers, and appealing for English speakers. But, even if regularized so as to be easier than English or Latin, its structure is more complex compared with Esperanto and Ido.

\section{(11) Socio-linguistic Profile}

After the closing of IALA in 1953, Interlingua no longer had much financial support. In 1955 the Union Mundial pro Interlingua was founded, with about 30 people. After fifty years, no more than 75 people took part in an Interlingua international meeting.

So, we can estimate about one hundred fluent Interlingua speakers in the EU, most of who surprisingly come from Scandinavia. The quality of literature produced is good but very small. As of February 3, 2005 Wikipedia had 1,368 entries in Interlingua, fewer than Ido.

\section{Summary and Concluding Remarks}

"The languages that eventually became standard French, German, Spanish, Italian, and English are, in part, invented. They were usually the result of combining elements of all the various idioms spoken in a region and then standardizing the grammar. However, once a common language became accepted, it created its own mystique of permanence. People came to think of it as their ancestral tongue and the cultural tie that bound them together." (Rifkin 2004:169)

Language planning is not a novelty in European language history, but choosing a rationally constructed language for the purposes of 
human rights in a super-national institution such as the European Union should be regarded as a unique fact in history. Certainly, if this were to happen, the IAL would create "its own mystique of permanence," to paraphrase Rifkin, after the first generation from its introduction in school. The only other historically similar phenomenon was the Modern Hebrew revival. After the first generation, the language was fully naturalized, obeying the laws of every natural language (Hagège 2000).

If English officially became the common language of every European, it's hard to believe that other languages wouldn't retreat even more quickly than at present from many contexts in everyday life. Probably, the uncertainty of the language norm (British or American?) would give rise to a third, continental, with unique structural properties emerging after a generation. Undoubtedly, as has been said, English lacks the proper characteristics to serve as an effective IAL for the European Union.

Similar considerations can be made about Latin. Structural analysis showed that Latin is complex, rich in irregularities, without a standardized pronunciation and familiar only to few EU citizens. Moreover, as already indicated, Latin as an IAL in contemporary European Union would follow a Christian-based view of 'Europeness', which is not generally accepted by Europeans themselves, so this language seems unsuitable to serve as the common language (Rifkin 2004). In addition, Latin as an IAL inevitably gives one the feeling of being transported at least five centuries in the past.

Interlingua certainly has been well constructed, although it has some irregularities due to its basically Romance character, which favors southern Europeans without any regard to the other two great linguistic family trees present in Europe: the Germanic and Slavic languages, not to mention others. The limits of Ido are quite the same.

No longer young, Esperanto is over 100 years old and has respected the linguistic habits of Romance speakers (lexicon), 
24 The European Union's Need for an International Auxiliary Language

German speakers (word order, syntax), and Slavic speakers (verb structure). Contrary to Bergen (2001), there is no evidence of structural distance between so-called native speakers of Esperanto and the rest of the speech community (Corsetti et al. 2004). Even if Esperanto were to serve as the Dachsprache (tegment language) of the other European languages, its structure is distant enough from that of any official EU language, so not to endanger them.

Compared to other IALs and English, Esperanto has the highest degree of hybridism, and respects the language habits of most Europeans (see Appendix). For some analysts, its evolution even shows some structural traits comparable with 'exotic' (in respect of the origins of Esperanto itself) languages, such as Turkish, Hungarian, Finnish or even Chinese: Esperanto may even respect, in some part, Finno-Ugric habits (Piron 1981). European or Asian language as it may be, Esperanto can certainly serve as the common language of European citizens. The only other choice is to launch a new IAL specifically designed for the EU, but without any guarantee of its success. 
Federico Gobbo 25

\section{References}

Albani, P. \& B. Buonarroti. 1994. Dizionario delle Lingue Immaginarie. Bologna: Zanichelli.

Angelino, G. 1988. L'Europa alla Ricerca di Una Lingua Comune. L'Idea Liberale 3, 12-17. . 1999. De Praestanti Methodo Docendi et Discendi Linguam Latinam. Latinitas 12, 145-150.

Bausani, A. 1974. Le Lingue Inventate. Rome: Astrolabio-Ubaldini.

Bergen, B. 2001. Naturalization Processes in L1 Esperanto. Journal of Child Linguistics 28, 575-595.

Carlevaro T. \& R. Haupenthal. 1999. Bibliografio di Ido. Bellinzona: Hans Dubois.

Corsetti, R. 1994. A Mother Tongue Spoken Mainly by Fathers. Language Problems, Language Planning 3, 263-273. Amsterdam: Benjamins.

Corsetti, R., M. Pinto, \& M. Tolomeo. 2004. Regularizing the Regular: The Phenomenon of Overregularization in Esperanto-speaking Children. Language Problems, Language Planning 3, 261-282. Amsterdam: Benjamins.

DGI. 2005. Directorate General for Interpretation. Retrieved February 3 http://europa.eu.int/comm/scic/interpreting/tech_relay_en.htm. . 2003. Directorate General for Interpretation. Annual Report.

Duggan, S. (ed.) 1945. International Auxiliary Language AssociationGeneral Report. New York: IALA.

Duranti, A. 1997. Linguistic Anthropology. Cambridge: Cambridge University Press.

Jung, Y.-H. 2004. English, Unish and an Ideal International Language: From a Perspective of Speech Sound and Writing System. Journal of Universal Language 5, 21-36.

Gazzola, M. 2003. La Relazione fra Costi Economici e Costi Politici del Multilinguismo nell'Unione Europea. Master's Thesis. Milan: Bocconi University.

Gledhill, C. 2000. The Grammar of Esperanto: A Corpus-based 
26 The European Union's Need for an International Auxiliary Language

Description. Muenchen:Lincom Europa.

Gode, A. 1962. Standard Average European-English. International Language Review 8, 3-10. Denver, CO: Floyd \& Evelyn Hardin.

Hagège, C. 2000. Halt à la Mort des Langues. Paris: Jacob.

Haskala. 2005. Encyclopcedia Britannica. Retrieved January 13 http://www.britannica.com/eb/article?tocId=9039461.

Holzhaus, A. 1969. Hilelismo. Projekto pri la Solvo de la Hebrea Demando. In U. De Ludovikito \& E. Joykampf (eds.), Hebreo el la Geto 359-441. Kioto: Dai Nippon.

. 1970. Doktoro kaj Lingvo Esperanto. Helsinki: Fondumo Esperanto.

Large, A. 1985. The Artificial Language Movement. Oxford: Blackwell.

Martinet, A. 1989. The Proof of the Pudding. In K. Schubert \& D. Maxwell (eds.), Interlinguistics. Aspects of the Science of Planned Languages. Trends in Linguistic 42, 3-5. Berlin: Mouton de Gruyter.

Meisl, J. 1917. Der Hillelist. Der Jude 4. Berlin: Martin Buber.

Peano, G. 1904. De Latino sine Flexione. Lingua Auxiliare Internationale. Revista de Mathematica 8, 74-83. Torino: Giuseppe Peano.

Pennacchietti, F. 1987. L'internazionalità dell'Esperanto e il Carattere Degli Elementi Indoeuropei in Esso. In A. Chiti-Batelli (ed.), Quale Lingua Perfetta? 27-53. Rome: Lacaita.

Phillipson, R. 2004. English-Only Europe? Challenging Language Politics. New York: Routledge.

Piron, C. 1981. Esperanto: European or Asiatic Language? Esperanto Documents 22A, 1-32. Rotterdam: UEA.

Rifkin, J. 2004. The European Dream. New York: Penguin.

Rowling, J. 2003. Harrius Potter et Philosophi Lapis. London: Bloomsbury Publishing PLC.

Tsuda, Y. 2004. A Critique of English as a Common Language for Perspective. Nagoya: Nagoya University.

Zamenhof, L. 1905. Fundamento de Esperanto. Paris: Hachette. 1929. Originala Verkaro. Leipzig: Ferdinand Hirt. 


\section{Appendix}

Table 2. A Structural Analysis of IAL Candidates for the EU

\begin{tabular}{|c|c|c|c|c|c|}
\hline & English & Latin & Esperanto & Ido & Interlingua \\
\hline Phonology & $\begin{array}{l}12 \text { vowels, } \\
25 \text { cons. }\end{array}$ & $\begin{array}{l}5 \text { vowels, } \\
19 \text { cons. }\end{array}$ & $\begin{array}{l}5 \text { vowels, } \\
23 \text { cons. }\end{array}$ & $\begin{array}{l}5 \text { vowels } \\
21 \text { cons. }\end{array}$ & $\begin{array}{l}5 \text { vowels, } \\
21 \text { cons. }\end{array}$ \\
\hline $\begin{array}{l}\text { Writing } \\
\text { system }\end{array}$ & $\begin{array}{l}\text { complex } \\
\text { etymologic } \\
\text { al principle }\end{array}$ & $\begin{array}{l}\text { complex } \\
\text { etymologic } \\
\text { al principle }\end{array}$ & $\begin{array}{l}\text { strict } \\
\text { phonemic } \\
\text { principle } \\
\text { (but it's not } \\
\text { ASCII or } \\
\text { Querty } \\
\text { compliant) }\end{array}$ & $\begin{array}{l}\text { loose } \\
\text { phonemic } \\
\text { principle }\end{array}$ & $\begin{array}{l}\text { strict } \\
\text { etymologica } \\
1 \text { principle } \\
\text { (but with a } \\
\text { quasi- } \\
\text { phonemic } \\
\text { alphabet in } \\
\text { alternative) }\end{array}$ \\
\hline Word order & SVO & SVO & $\begin{array}{l}\text { SVO, OSV, } \\
\text { SOV }\end{array}$ & SVO & SVO \\
\hline $\begin{array}{l}\text { Language } \\
\text { substrata }\end{array}$ & $\begin{array}{l}\text { Anglo- } \\
\text { Saxon, } \\
\text { Latin, } \\
\text { Old Norse, } \\
\text { Medieval } \\
\text { French }\end{array}$ & $\begin{array}{l}\text { Ancient } \\
\text { Greek }\end{array}$ & $\begin{array}{l}\text { Yiddish, } \\
\text { German, } \\
\text { Latin, } \\
\text { Ancient } \\
\text { Greek, } \\
\text { English } \\
\text { French, } \\
\text { Russian, } \\
\text { Polish, } \\
\text { Hebrew }\end{array}$ & $\begin{array}{l}\text { Latin, } \\
\text { Ancient } \\
\text { Greek, } \\
\text { French, } \\
\text { English, } \\
\text { Italian }\end{array}$ & $\begin{array}{l}\text { Latin, } \\
\text { English, } \\
\text { French, } \\
\text { Italian, } \\
\text { Spanish/ } \\
\text { Portuguese, } \\
+ \\
\text { German, } \\
\text { Russian }\end{array}$ \\
\hline
\end{tabular}


28 The European Union's Need for an International Auxiliary Language

Table 3. Sociolinguistic Profiles of IAL Candidates for the EU

\begin{tabular}{|c|c|c|c|c|c|}
\hline & English & Latin & Esperanto & Ido & Interlingua \\
\hline $\begin{array}{l}\text { Language } \\
\text { vitality }\end{array}$ & $\begin{array}{l}\text { the } \\
\text { strongest, } \\
\text { but } \\
\text { controversial } \\
\text { IAL role }\end{array}$ & $\begin{array}{l}\text { small, but } \\
\text { with a very } \\
\text { strong } \\
\text { tradition }\end{array}$ & $\begin{array}{l}\text { good, with } \\
\text { naturalizatio } \\
\text { n phenomena }\end{array}$ & $\begin{array}{l}\text { very small, } \\
\text { in danger }\end{array}$ & $\begin{array}{l}\text { small but } \\
\text { very active }\end{array}$ \\
\hline $\begin{array}{l}\text { Speech } \\
\text { community } \\
\text { in EU }\end{array}$ & 57 millions & 1,000 & 25,000 & 100 & 100 \\
\hline $\begin{array}{l}\text { Wikipedia } \\
\text { entries in } \\
05 \text {, Feb } 3\end{array}$ & 465,415 & 2,568 & 20,389 & 2,187 & 1,368 \\
\hline $\begin{array}{l}\text { Literature } \\
\text { degree }\end{array}$ & $\begin{array}{l}\text { the highest } \\
\text { in the world } \\
\text { in every } \\
\text { field }\end{array}$ & $\begin{array}{l}\text { high, but } \\
\text { little modern } \\
\text { production }\end{array}$ & $\begin{array}{l}\text { good; some } \\
\text { fields need } \\
\text { to be } \\
\text { covered } \\
\text { more } \\
\text { extensively }\end{array}$ & $\begin{array}{l}\text { bad, almost } \\
\text { no modern } \\
\text { production }\end{array}$ & $\begin{array}{l}\text { small } \\
\text { production }\end{array}$ \\
\hline $\begin{array}{l}\text { Familiarity } \\
\text { for EU } \\
\text { citizens }\end{array}$ & $\begin{array}{l}\text { L1 for } \\
\text { English, } \\
\text { some } \\
\text { transparency } \\
\text { for German } \\
\text { and } \\
\text { Scandinavia } \\
\text { n speakers } \\
\text { (175 million } \\
\text { EU citizens). }\end{array}$ & $\begin{array}{l}\text { some } \\
\text { transparency } \\
\text { for Romance } \\
\text { and English } \\
\text { speakers } \\
\text { (226 million } \\
\text { EU citizens). }\end{array}$ & $\begin{array}{l}\text { some } \\
\text { transparency } \\
\text { of the } \\
\text { lexicon for } \\
\text { Romance, } \\
\text { German, } \\
\text { English and } \\
\text { Slavic } \\
\text { language } \\
\text { speakers } \\
\text { (395 million } \\
\text { EU citizens). }\end{array}$ & $\begin{array}{l}\text { some } \\
\text { transparenc } \\
\text { y of the } \\
\text { lexicon for } \\
\text { Romance } \\
\text { and English } \\
\text { speakers } \\
\text { (226 } \\
\text { million EU } \\
\text { citizens). }\end{array}$ & $\begin{array}{l}\text { immediate } \\
\text { readable for } \\
\text { Romance } \\
\text { speakers, } \\
\text { good } \\
\text { transparency } \\
\text { for English } \\
\text { speakers } \\
\text { (226 million } \\
\text { EU } \\
\text { citizens). }\end{array}$ \\
\hline
\end{tabular}

